\title{
Application of Strict Liability Principles Against Illegal Karst Rock Mining Leading to Environmental Damage
}

\author{
Yeni Widowaty ${ }^{1, *}$, Gatot Supangkat Samidjo ${ }^{2}$, and Dakha Hadi Nugraha ${ }^{1}$ \\ ${ }^{1}$ Master of Law, Universitas Muhammadiyah Yogyakarta, Indonesia \\ ${ }^{2}$ Agrotechnology Department of Agriculture Technology, Universitas Muhammadiyah Yogyakarta, \\ Indonesia
}

\begin{abstract}
Illegal mining of karst rocks in Gunungkidul Regency is increasingly rampant, resulting in environmental damage and casualties. The proposed problem is how can the principle of strict liability be applied to illegal karst mining actors? What is the concept that should be done in the future to abolish illegal karst rock mining to prevent further environmental damage? The research was a socio-legal study with primary and secondary data. The research was conducted in Gunungkidul, Indonesia by taking samples in the village of Ponjong. The results of the study showed that the perpetrators of illegal karst rock mining so far have never been imposed to the principle of strict liability. Ironically, there have been no objections from the public so far against mining companies. The community around the mining area is employed by the company, while the needs of the community are met. Hence, no protest occurred even though the mining caused environmental damage. The concept that should be carried out in the future to prevent further illegal mining is the improvement of law enforcement. Although action has been taken against illegal miners with revocation of permits, a reformulation of regulations by imposing criminal sanctions on perpetrators is necessary to become a deterrent.
\end{abstract}

\section{Introduction}

The increase in population also requires a large area of land to carry out activities and utilize natural resources to meet their daily needs. Excessive exploitation of natural resources will have an impact on decreasing the sustainability of natural resources and environmental functions. Environmental problems that arise are the increasing environmental damage as a result of the use of natural resources to increase local revenue without paying attention to environmental sustainability. Developments that rely on the use of natural resources that have occurred until now have not been balanced with prudence in their management.

*Corresponding author: yeniwidowaty@umy.ac.id 
One form of exploitation of natural resources is mining activities. Mining activities also occur in Indonesian territory, one of which is in Gunungkidul Regency, Yogyakarta Special Region Province. In an effort to increase development, each region seeks to explore and utilize various potential natural resources that exist in each region. In the mining sector, for example, utilization is not only carried out by entrepreneurs or capital owners but also by the community. In fact, mining activities carried out by the community are often without a permit. They also do not care about environmental or work safety aspects, let alone the improvement of the post-mining environment.

Limestone mining activities in the karst area in Bedoyo Village, Ponjong District, are quite damaging to the environment. According to Cahyadi and Henky Nugraha [1], the karst area of Ponjong District, Gunungkidul Regency, is located in the tropics and makes this area a potential carbon sink because this area has very high rainfall. The more rainfall, the more intensive the karstification process so that carbon absorption is quite high because, in the karstification process, carbon absorption occurs, which means it can reduce global warming. According to Cahyadi [2], limestone mining in the karst area of Gunungkidul Regency is carried out by exfoliating the karst cones either manually or with heavy equipment. This mining process causes the loss of the epikarst layer, a thin layer on the surface of the land that functions to hold water. With mining activities, there will be a reduction in carbon sequestration and damage water systems and habitats for endemic animals such as bats, snakes, wallet birds, and long-tailed monkeys.

According to Santosa [3], the rampant mining activity in the karst area of Gunungkidul Regency has resulted in increasing land damage. Most mining activities that trigger land damage are community mining, especially illegal mining that is not licensed. The income factor affects the number of mining activities in the Bedoyo karst area, Ponjong District, Gunungkidul Regency. The wider the mining area leads to the higher the level of land damage [4]. The ever-increasing prevalence of limestone mining in the karst area causes damage to the karst landscape and referring to Government Regulations No. 26 of 2008 concerning the National Spatial and Regional Planning, which states that the karst area is a protected geological area. On February 7, 2011, The Gunungkidul Regency Government issued a policy in the form of a Regent's Circular Letter Number 540/0196, which banned mining in the karst area.

From data from the Ministry of Industry and Trade, there are 9 (nine) karst mining companies that employ 908 workers in Gunungkidul. Still, there are undetected illegal miners who carry out mining erratically, so that environmental damage is unavoidable.

\subsection{Problem Formulation}

1) How can the principle of strict liability be applied to perpetrators of illegal karst rock mining that causes detrimental environmental damage for the victims?

2) What is the concept that should be implemented in the future to prevent further illegal mining?

\subsection{Literature Review}

\subsubsection{Mining}

According to Law of The Republic of Indonesia Number 3 of 2020 About "Mineral And Coal Mining Concerning Amendment "To Law Number 4 of 2009 Concerning Mineral And Coal Mining: "Mining is part or all of the stages activities in the framework, management and exploitation of mineral or coal covering investigation general, 
exploration, feasibility study, construction, mining, processing and/or refining or development " and for utilization, transportation and sales, as well as post-mining activities".

From the definitions of mining above, it can be seen that mining is « an effort to extract and utilize » excavated materials. In essence, the development of the mining and energy sector seeks a process of developing potential mineral and energy resources to be utilized efficiently and optimally for the maximum benefit for people.

Mineral resources are non-renewable resources. Therefore, its application is expected to be able to maintain a balance and safe performance and preservation of the environment and the surrounding community. Some of the factors that affect the mining business are as follows:

a. Changes in the tax system.

b. Policies in the environment.

c. Bad economic situation.

d. Poor deposit or metal prices.

e. Unstable political situation.

\subsubsection{Types of Mining}

Since the change in the coal mineral law, the types of mining have been added. According to "Government Regulation Of The Republic Of Indonesia Number 96 Year 2021 Concerning Implementation of Mineral And Coal Mining Business Activities Article 2 paragraph (1) determines that Mineral and Coal Mining is grouped into 5 (five) groups as follows":

a. Radioactive minerals include uranium, thorium, and other radioactive minerals;

b. Metallic minerals

c. Minerals and minerals

e. Coal includes asphalt rock, coal, biturment solid, and peat."

\subsubsection{Illegal Mining}

Illegal mining or mining without a permit is a business carried out by a person, group or company in the mining sector that are legal entities which in their business activities do not have permits and government agencies in accordance with applicable laws and regulations. Therefore, if a permit, recommendation is given to an individual, group, or company by a government agency outside the provisions of the applicable laws and regulations, it can be categorized as mining without a permit or illegal mining a business in the mining sector carried out by an individual

Small-scale or small-scale miners are often connoted with illegal mining because they do not have an official license to run their business, use their materials and production tools (including mercury), and distribute their mining products (to the export market). The "wild west" life pattern of some smallholder mining is considered to interfere with the social life of the surrounding community, their activities that damage the environment and some public facilities (for example by using public roads to transport their illegal products), interfere with the owner of official mining permits, making small-scale mining activities often have to deal with law enforcement.

\subsubsection{Karst Rock}

Karst is a special type of landscape formed by the dissolution of dissolved rock, including limestone and dolomite. Karst areas have aquifers that can provide a large supply of water. 
[6]. According to Milanovic Karst this is a typical landscape in Slovenia which spreads to Italy in the form of limestone [7]

Based on the understanding in the "General Provisions of the Minister of Energy and Mineral Resources Decree No. 17 of 2012 concerning the Determination of Karst Landscape Areas, it is stated that what is meant by karst is" a landscape formed due to the dissolution of water in limestone and/or dolomite. The definition of karst landscape area is karst that shows certain exokarst and endokarst. Exokarst is karst on the surface, while endokarst is karst on the bottom surface. Exokarst consists of permanent springs, karst hills, dolina, uvala, polje and lakes. Endokarst consists of underground rivers and speleothems."

Karst is a 'topographical type formed in limestone, gypsum, and other rocks by dissolution characterized by sinkholes, caves, and underground drainage areas.' Karst areas constitute about 10 percent of the world's land surface, and there is widespread concern about the effects Human activities on the karst environment Many human activities can have a negative impact on karst areas, including deforestation, agricultural practices, urbanization, tourism, military activities, and water exploitation, mining and quarrying [8].

The existence of carbonate rocks/karst aquifers has various types of landscapes. The simplest and most pragmatic classification of the landscape is plains, hills, and mountains. These three landscapes are classified using relative slope and relief classes, which are calculated based on a global digital elevation model with a resolution of $250 \mathrm{~m}$ [9]. The impact of damage due to mining will be different, the bigger the mining, the wider the impact on environmental damage.

\subsubsection{Environmental Damage}

Article 1, number 17 of Law No. 32 of 2009 concerning Environmental Protection and Management stipulates » that: "Environmental damage is a direct and/or indirect change to the physical, chemical, and/or biological properties of the environment that exceeds the standard criteria for environmental damage". Furthermore, to determine the limit of environmental damage, there is a standard limit for environmental damage as specified in the law. Article 1 number 15 Environmental Law 32 of 2009 stipulates that: "The standard criteria for environmental damage is a measure of the limit of changes in the physical, chemical, and/or biological characteristics of the environment that can be tolerated by the environment in order to continue to preserve its functions".

Environmental damage can occur due to human factors (anthropogenic) and natural factors. Environmental damage due to human factors is the impact caused by an activity carried out by humans, such as limestone mining. Environmental damage due to natural factors is the impact caused by natural factors such as rainfall. Damage recovery can be made by reclamation. According to the Minister of Energy and Mineral Resources Number 7 of 2014 concerning the Implementation of Reclamation and Post-Mining in Mineral and Coal Mining Business Activities, what is meant by reclamation is an activity carried out throughout the stages of the mining business. To organize, restore, and improve the quality of the environment and ecosystem to function again according to its designation.

Karst exploitation can have serious impacts and threaten the sustainability of the ecosystem. There are two ecosystems threatened by karst mining activities, namely the forest ecosystem at the top (exokarst) and the cave at the bottom (endokarst). Among environmentalists, the karst area is an area that is very sensitive to environmental changes. This condition is caused because the karst area has a low carrying capacity and is difficult to repair if it is already damaged. Human activities that cause damage to the karst environment include mining, agriculture, animal husbandry, logging, road construction, and tourism. These activities result in changes in the karst landscape, loss of springs, decreased biodiversity, flooding, and surface water pollution. 


\subsubsection{Strict Liability}

Little about strict liability has evoked much agreement among commentators except for their opposition to it. Most but not all philosophers of law regard strict liability in the criminal law as unjust. To be sure, the opposition of commentators is highly qualified. Legal philosophers are more tolerant of strict liability in tort law than in criminal law, less vehement when punishments are relatively lenient, and sometimes prepared to allow the exigencies of law enforcement to override considerations of justice. These concessions, however, are made in a general climate of hostility to strict liability [10].

In strict liability, where a defendant's activity is tortious if "abnormally dangerous," the Restatement considers community norms crucial. It balances the threats associated with the activity against "any usefulness it may have for the community." It also considers whether the activity is one of "common usage," defined to mean one carried on "by many people in the community." [11].

\section{Methodology}

This is an empirical juridical or socio-legal. Primary data was obtained by conducting interviews with respondents, namely the people who carried out karst mining in Ponjong Gunungkidul. The people interviewed in this study are people who carry out mining in the village of Bedoyo Ponjong Gunungkidul. Interviews were also conducted with a collector of Karst mining products from the community. While the secondary data consists of: a. Primary Legal Materials sourced from statutory regulations and legal documents, b. Secondary Legal Materials sourced from books and legal writings and textbooks, In addition, interviews with resource persons from the district environmental office were also conducted. The research was conducted in Gunungkidul Regency, DIY, where many areas of Karst rock are illegally mined. The analysis used in this study uses a flow model of analysis [5].

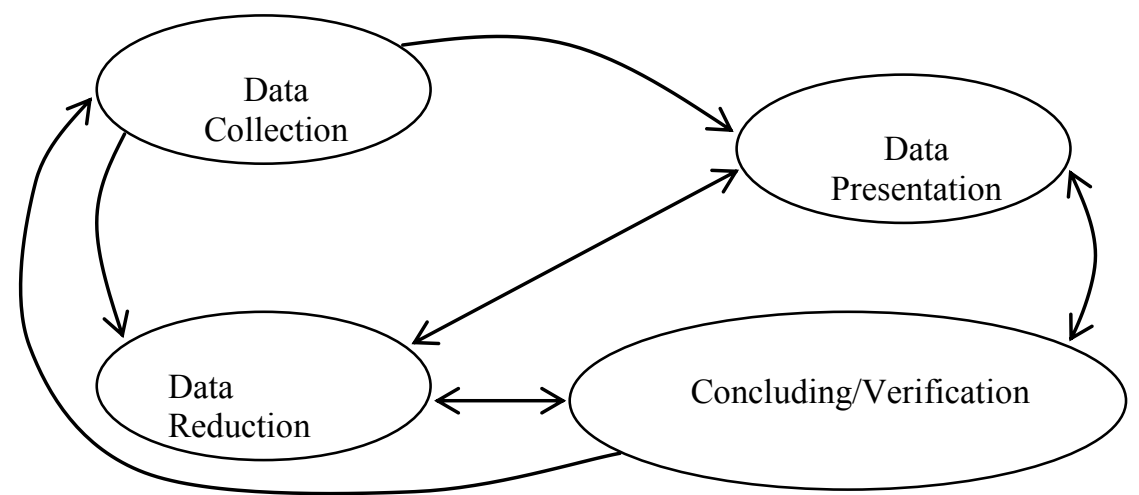

Fig. 1. Flow model of analysis

The data obtained from research, both library research and field research, were processed and analyzed critically analytically and presented in a qualitative descriptive manner. In connection with legal research to seek answers to legal issues that explore the problem of applying the principle of strict liability in illegal karst rock mining, it is important to conduct an analysis by not only emphasizing the major premise originating from formal and material law but also looking for premises from theories. which exists. analysis model in accordance with the flow analysis model above. 


\section{Results and Discussion}

\subsection{Application of Strict Liability Principles Against Illegal Karst Mining Actors who Cause Environmental Damage}

Gunungkidul Regency is the largest Regency in Special Region of Yogyakarta (DIY) and has extraordinary natural resources, especially in its karst landscape. The karst area in Gunungkidul is in a Geological Protected Area with an area of 80,704 hectares and spread over 11 sub-districts. The eleven sub-districts include Ponjong, Semanu, Girisubo. Rongkop, Tepus, Tanjungsari Districts. With the potential of these extraordinary natural resources, not a few people flock to use them as mining materials. Mining in Gunungkidul Regency will have a major impact on the sustainability of the area if it is carried out continuously. The impact is not only damage to soil conditions but also the surrounding ecosystem.

The results of the field research show that until now, many miners still carry out illegal mining in Gunungkidul Regency. According to Mr. Sarwono as the owner of CV. Darmo Sejahtera, mining in Gunungkidul can be carried out properly if it gets a permit and is carried out according to applicable regulations. He also explained that the sources of livelihood for the people of Gunungkidul are stone mining and plantations. CV. Darmo Sejahtera only received a permit in early 2021 and will operate in May 2021. During the permit process, he did not carry out mining because he was aware of the impacts and consequences of illegal mining. According to Mr. Sarwono, the process of getting a permit is also not easy. There are several first, namely having to be able to manage the place after mining so that there is no damage to the ex-mining area. The second is that the mining area is located near a residential area, so the relevant agency has issued a mining permit to prevent landslides from occurring in residential areas. Mining products will be used as backfill and building materials. The excavated land produced can also be used by local residents as agricultural land because, according to Sarwono, so far, this land cannot be used and utilized by local residents. According to him, it is regrettable if there are illegal mining elements that do not know the impact produced after mining. If it is carried out continuously and in a good place, then the resulting impact will be a bad impact for life to come. As a result, people's land becomes damaged and cannot be used properly. During the licensing process, it is not as easy as imagined. There are so many obstacles that must be resolved one by one, and one of them is that many people reject mining in that area.

According to Joko Untoro, S.T, as the Head of the Planning and Environmental Impact Assessment Section at the Gunungkidul Regency Environment and Forestry Service, he explained that mining in Gunungkidul Regency has actually been properly monitored by the relevant Department. However, there are many irresponsible people who participate in mining secretly or illegally without first applying for a mining permit. According to Untoro, illegal mining in Gunungkidul is one of the efforts made for survival. For example, mining employees carry out mining to obtain mining products that are used for daily needs. But whatever the reason, it will not be justified, and if caught doing illegal mining, anyone should be subjected to sanctions.

Furthermore, Untoro said that not long ago, there was even a case of miners being buried during mining. Surawan (27) mined stones in Umbulrejo Village, Ponjong, Gunungkidul Regency. Actions that have been taken by the Environment and Forestry Service are to monitor disaster-prone areas and frequently conduct inspections or direct visits to the monitored areas.

According to Eko, in that location, there are still a number of points that have the potential for landslides. "There are about three points that have the potential for landslides," said Eko, Sunday, March 5, 2017. The head of the Yogyakarta Veterans UPN Disaster 
Management Study Center explained that the landslide potential was due to the high rainfall in recent weeks. In addition, landslides can occur if the karst rock hill has a vibration trigger.

Environmental damage to karst areas is usually caused by mining, agricultural extensification, deforestation, and especially land-use change. Mining is the heaviest contributor to the damage in karst areas and requires a relatively long time for conservation treatment. Mining in karst areas can reduce the storage capacity or capacity of limestone for rainwater, and water trajectories can change or move places, while water sources will also decrease. The results of the research show that there have been two parties who were convicted of mining without a permit, thus violating the Mineral and Coal Law. Due to mining carried out without a permit, it causes environmental damage the results of the research show that there have been two parties who were convicted of mining without a permit, thus violating the Mineral and Coal Law. Due to mining carried out without a permit, it causes environmental damage.

Indeed, both legal and illegal mining has the potential to damage the environment, but for legal miners, the location is determined to be far from settlements, and there are some whose licenses have expired and cannot be extended. Meanwhile, for illegal mining, the potential for environmental damage cannot be predicted because the location is uncertain. The impact of environmental damage, of course, causes victims, especially the community around the mining site.

Table 1. Wonosari District Court's decision for limestone mining 2016-2017

\begin{tabular}{|c|c|c|}
\hline No & Case Number & Decision \\
\hline 1 & $\begin{array}{l}\text { No: } \\
\text { 2/Pid.B/LH/2017/PN } \\
\text { WNO }\end{array}$ & $\begin{array}{l}\text { 1. To declare that the Defendant } \\
\text { KUSMIYANTO was legally and convincingly } \\
\text { proven guilty of committing a criminal act of } \\
\text { mining without a permit and violating Article } \\
158 \text { of Law no. } 4 \text { of } 2009 \text { and sentenced to } \\
\text { imprisonment for } 5 \text { (five) months and a fine of } \\
\text { Rp. 3,000,000,- (three million rupiah) } \\
\text { subsidiary to imprisonment for } 1 \text { (one) month; }\end{array}$ \\
\hline 2 & $\begin{array}{l}\text { No: } \\
66 / \text { Pid.Sus/2016/PN } \\
\text { Wno }\end{array}$ & $\begin{array}{l}\text { Defendant Country I. MARTINI MARDI } \\
\text { MULYONO, Defendant II. SUPARDAL } \\
\text { Defendant III. DARU SAYANG DIPUTRA } \\
\text { was legally proven and guilty of committing a } \\
\text { mining crime without a Mining Business Permit } \\
\text { as regulated in Article } 158 \text { of Law Number } 4 \text { of } \\
2009 \text { in conjunction with Article } 55 \text { paragraph } \\
\text { (1) } 1 \text { of the Criminal Code so that they were } \\
\text { sentenced to imprisonment of } 7 \text { (seven) months } \\
\text { each with a period of } 7 \text { (seven) months. } 1 \text { (one) } \\
\text { year trial and a fine of Rp. } 15,000,000 \text {,- (fifteen } \\
\text { million rupiah) subsidiary } 5 \text { (five) months in } \\
\text { prison. }\end{array}$ \\
\hline
\end{tabular}

To protect karst areas from irresponsible human activities, the government has actually developed regulations governing the protection of karst areas, both in terms of management and policies related to spatial planning. One of them is the Decree of The Minister of Energy and Mineral Resources No. 1456 of 2000 concerning Guidelines for the Management of Karst Areas. In the regulation, the karst area is divided into three; Class I Karst Area, which is a protected area in which mining activities are not allowed. Other 
activities may be carried out as long as they do not interfere with the karstification process and do not damage the function of the karst area. Class II Karst Area is a karst area in which mining activities may be carried out accompanied by Environmental impact analysis studies. Class III Karst Area is a huge area of karst. The size of these mine reserves attracts people to mining limestone, although not all of these activities have the requirements for land certificates, building permits, environmental permits, and so on.

From the results of the study, there have been no community victims of environmental damage who have sued for compensation to the miners. This is because individual miners are usually the people around the mining site. Indeed, not all people around the Karst Area do mining. Some work as carpenters in the city or laborers.
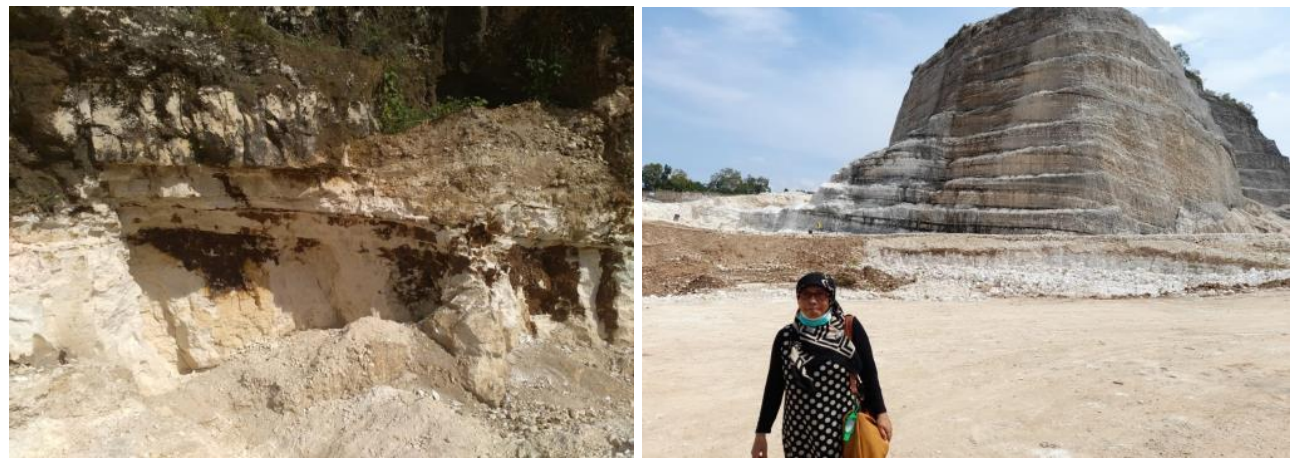

Fig. 2. Karst area 1 (left) and Karst area 2 (right)

According to the author, this condition can be analyzed with the strict liability doctrine. In Law No. 32 of 2009 concerning "the Protection and Management of the Environment" in Article 88:

"Everyone, whose actions, business, and/or activities use B3, generates and/or manages B3 waste, and/or poses a serious threat to the environment, is absolutely responsible for the losses that occur without the need to prove the element of fault." The explanation of the law includes that: Article 88 What is meant by "absolute responsibility" is "that the element of guilt does not need to be proven by the plaintiff as the basis for payment of compensation. The amount of compensation that can be charged to polluters or environmental destroyers, according to this Article, can be determined to a certain extent."

In strict liability, the maker of a criminal act can be convicted only because the elements of a criminal act have been fulfilled regardless of whether the maker is guilty or not. Not all criminal acts can apply this absolute responsibility principle, but only certain crimes, namely: if the crime is committed by someone in carrying out his profession, which contains elements of adequate expertise (expertise), social responsibility (social responsibility) and corporations supported by a code of ethics.

James E. Krier argues that the doctrine of absolute responsibility can be of great help in the judiciary regarding environmental causes, because many activities that experience harm to the environment are harmful acts, for which the liability provision can be applied.

The provisions of Article 88 are amended by Act Number 11 of 2020 concerning Job Creation so that it reads, "Everyone whose actions, business, and/or activities use B3, generates and/or manages B3 waste, and/or poses a serious threat to the environment. is absolutely responsible for the losses that occur from its business and/or activities.

"The omission of the word "without the need to prove the element of fault" confuses the meaning of «strict liability» in this article so that the explanation of the article needs to 
include the characteristics of the strict liability concept such as the elements that need to be proven in the plaintiff's lawsuit or concept exceptions. In Environmental Law, Strict Liability is a powerful tool for environmental law to ensnare corporations without proving an element of guilt, not anymore. It is not easy to apply the principle of strict liability for illegal karst mining actors, especially business entities that commit violations.

\subsection{Concepts That Should Be Carried Out In The Future To Prevent Further Illegal Mining}

Some Indonesians accept what happened as fate, such as some residents who live around the Gunungsewu karst, especially residents of Bedoyo village, Ponjong Gunungkidul District, who so far do not protest against the mining and have not even filed a compensation claim.

In 2017 , the community was made to be very dependent on entrepreneurs by giving the community the convenience of being able to owe/borrow money to entrepreneurs if needed, for example, to pay their children's tuition fees which were then paid for later with mining karst rocks. Some companies whose licenses have been revoked are no longer mining karst rocks. However, it turns out that there are companies whose licenses have been revoked and are still producing. This is because the people who carry out mining activities, then the results are bought by the company.

Ideally, with the strict liability doctrine that the author put forward above, the community does not need to be in debt, but companies with their own awareness provide compensation to residents. The provisions regarding strict liability of the Environmental Law, which have been amended by the Job Creation Act, give rise to different interpretations among experts. With the omission of the word "without the need to prove the element of error," there are those who argue that it does not change the meaning so that it is still obligatory to compensate if there is environmental damage. However, another opinion says that in the Job Creation Act, the element of error must still be proven.

Romli Atmasasmita argues that strict liability crimes can be applied if:

a. The crime is not a serious one.

b. The applicable penalty is light.

c. The condition for the existence of "mens rea" will hinder the purpose of the legislation.

d. Crimes committed directly constitute coercion of the rights of others.

e. According to the applicable law, "mens rea" does not need to be proven casuistically.

In order to provide more legal protection to victims and illegal mining no longer occurs, strong law enforcement is needed. Nolan's research results show that: "there are 10 factors influencing the participation of law enforcement officers in crime. These factors are: (a) organizational attitudes/beliefs; (b) utility in community relations; (c) organizational selfpreservation; (d) efficacy of police involvement; (e) priority of resource allocations; (f) supportive organizational policies and practices; (g) individual attitudes/beliefs; (h) professional self-preservation; (i) work-related difficulties; and (j) organizational commitment."[12].

If law enforcement against existing rules is implemented properly and the voice of the community is also heard, illegal mining will be reduced. The voices of the community include the Coalition of People Care for the Sewu Mountains, calling on the Gunungkidul Regency Government and other parties to:

1. Stop the destruction of the Gunung Sewu Karst Landscape Area

2. The Government of Gunungkidul Regency is obliged to immediately stop the development process carried out by PT. Mount Samudra Tirtomas by sealing the location. 
3. Carry out the mandate of the Gunungkidul Regency Regional Medium Term Development Plan (RMTDP) to develop and optimize the orientation of regional economic development based on agriculture, fisheries, forestry, and tourism as well as other cultivation activities that environmentally friendly manner .

4. The Government of Gunung Kidul Regency is obliged to maintain and protect the Gunung Sewu KBAK as a protected geological area from any form of destruction and use by changing the landscape.

5. Inviting community elements to participate in preserving the landscape and ecosystem of Gunung Sewu Karst

\section{Conclusions}

So far, the principle of strict liability has never been applied to the perpetrators of illegal karst rock mining. This is because, so far, there have been no objections from the public against mining companies. The community around the mining area is employed by the company, and the needs of the community are met so that there is no protest even though the mining causes environmental damage. The change in the meaning of strict liability by the work copyright law does not affect the implementation in the field. The concept that should be carried out in the future so that there is no illegal mining that causes environmental damage, then law enforcement is improved. Although action has been taken against illegal miners with revocation of permits, in the future, there needs to be a reformulation of regulations by imposing criminal sanctions on perpetrators to become a deterrent.

\section{References}

1. A. Cahyadi, H. Nugraha, and F. Nucifera, (2013).

2. A. Cahyadi, in Semin. Nas. Perubahan Iklim Di Indones. (2010).

3. Santosa, J. Teknol. Pertan. Andalas 10, 14 (2006).

4. Kompasiana, (2016).

5. M. B. Miles and A. M. Huberman, Analisis Data Kualitatif (UI Press, Jakarta, 1992).

6. C. N. Edmonds, Q. J. Eng. Geol. Hydrogeol. 41, 261 (2008).

7. S. Milanovic, Environ. Geol. 51, 755 (2006).

8. W. H. Langer, US Geol. Surv. (2001).

9. N. Goldscheider, Z. Chen, A. S. Auler, M. Bakalowicz, S. Broda, D. Drew, J. Hartmann, G. Jiang, N. Moosdorf, Z. Stevanovic, and G. Veni, Hydrogeol. J. 28, 1661 (2020).

10. D. N. Husak, Can. J. Law Jurisprud. 8, 189 (2015).

11. C. C. Tilley, Yale Law J. 126, 1320 (2017).

12. J. J. Nolan and Y. Akiyama, J. Contemp. Crim. Justice 15, 111 (1999). 